\title{
Project Management Practice in Groundwater Construction Project in Ghana
}

\author{
Yaw Frimpong ${ }^{1, *}$, Jacob Oluwoye ${ }^{2}$ \\ ${ }^{1}$ Project Management, Groundwater Services, Sydney, Australia \\ ${ }^{2}$ Department of Community and Regional Planning, Alabama A \& M University, Alabama, USA
}

Email address:

yawfremps@yahoo.com (Y. Frimpong)

${ }^{*}$ Corresponding author

\section{To cite this article:}

Yaw Frimpong, Jacob Oluwoye. Project Management Practice in Groundwater Construction Project in Ghana. American Journal of Management Science and Engineering. Vol. 3, No. 5, 2018, pp. 60-68. doi: 10.11648/j.ajmse.20180305.14

Received: September 14, 2018; Accepted: October 26, 2018; Published: November 26, 2018

\begin{abstract}
The implementation of good project management practice effectively, is a way of improving future projects especially in groundwater construction projects. The lack of good project management principles may cause project delays, and higher costs. A fundamental principle of project management is that any project, regardless of its size or type, consists of three components: scope, budget, and schedule. The purpose of this paper is to investigate and examine how project Management practice in groundwater construction projects in Ghana. The research focuses on the issues of management practice in groundwater construction projects in order to recommend ways of improving management practices. The data were collected through a questionnaire survey sent to the managers, consultants and client's representative who had been involved in the construction of groundwater projects in Ghana. The survey covered the project management lifecycle: project initiation, planning, executing, monitoring/controlling the closing/evaluating processes of the project. The result of the data analysis reveals that: all three groups (managers, consultant and clients representative) generally agreed that most of the problems in the groundwater construction projects are human and management related. Furthermore, the results indicated that most of the projects did not have project management processes and procedures. The paper concludes with recommendations that the scope of the project is defined and a project management plan is developed be taken in the early stages (conceptual and planning, and evaluating phases) of the groundwater construction projects.
\end{abstract}

Keywords: Project Management Practice, Groundwater, Construction, Ghana

\section{Introduction}

The implementation of good project management practice effectively, is a way of improving future projects especially in groundwater construction projects. The lack of good project management principles may cause project delays, and higher costs. A fundamental principle of project management is that any project, regardless of its size or type, consists of three components: scope, budget, and schedule. Bagayaad and Song [1] case study reveals that many projects have been implemented without good project management practices.

With the focus on the Republic of Ghana (formerly Gold Coast), which is a developing country with a rapidly growing economy, the subject of project management in developing countries is addressed. Ghana is located on the West Coast of
Africa, and has a total area of $238,305 \mathrm{~km}^{2}$ with a projected population of 28.3 million [2]

The main uses of groundwater in Ghana are domestic water supply, small-scale irrigation and industrial. Over $95 \%$ of groundwater use in Ghana is for domestic water supply, mostly in rural areas and small towns [3]. Overall, around $40.4 \%$ of households in Ghana depend on groundwater for their water supply [4] - this is generally much higher in rural areas $(59 \%)$ than urban areas $(26 \%)$. Less than $5 \%$ of groundwater in Ghana is used for irrigation and watering of livestock and poultry [5-7]. Industrial use of groundwater in Ghana accounts for less than $1 \%$ of the total groundwater use. This includes large-scale commercial bottled water companies in the south of the country [ $3 \& 8]$. The main types of groundwater source in Ghana are boreholes with hand pumps, boreholes with electric pumps and hand dug 
wells. Grönwall [9] study paper aims to provide a picture of user practices and preferences in an area for long depending on groundwater.

The paper investigates the use of project management procedures and practice among the clients, consultants and contractors in groundwater construction projects in Ghana and presents the results of survey questionnaire conducted among personnel involved in the groundwater construction industry.

The water industry is one sector that has played a major role in the economy of the country especially in the rural communities in Ghana, which depend mostly on the groundwater. Groundwater may also be accessed from the community, private vendors or NGO-run kiosks, or through self-supply from own or shared wells and boreholes [10-12].

In effective project Management practice in groundwater construction projects, there should be a seriously monitoring, reviewing and auditing of activities as often as necessary in order to evaluate its performance and compare with the projected targets.

\section{Literature Review}

Quartey Jnr [13] indicated that groundwater projects have a life cycle comprising three distinct phases: (i) The preconstruction phase, during which activities such as feasibility, design and preparation of tender documents take place, (ii) The construction phase, during which the facility is built and commissioned. (ii) The operational phase, during which the facility is utilised to deliver the service to the user. In the generic model of project management processes developed by PMBOK, the project management processes are consisted of five sub-processes [14]: Initiating processes, Planning processes, Executing processes, Controlling processes and Closing processes.

The project management life cycle describes the high-level process of delivering a project and the steps you take to make things happen. Project Management Life cycle is really just a highfalutin way of describing the life of a project. It's how projects happen; how a project is taken from brief through to delivery. Every project has a start and end; it's born, matures and then 'dies' when the project life is complete [15]. Project life cycle phases create a roadmap to organize and manage any type of projects successfully. Therefore the project life cycle phases are essential for all the project managers' aim for completing projects effectively. The project management life cycle is an important concept of project management. It will be useful; to know five project life cycle phases for a successful project management [16] and understanding of the project life cycle [17]

Project management is the application of knowledge, skills, tools, and techniques to project activities in order to meet or exceed stakeholder needs and expectations from a project [14]. Golinia et el [18] study stated that The adoption of project management tools is an important factor in project success in both the short and long term. Muspratt [19] also gave a full discussion on the conditions affecting projects in less developed countries. Codas [20] presented development of project management in Brazil, while Cash and Roberts [21] gave the elements of successful project management of developing countries.

In an Abbasi and Al-Mharmah [22] study to measure the level of usage of the mentioned PM tools and to identify problems, benefits and obstacles affecting the implementation of such tools in Jordan. They discussed the effective project management practice would result in tangible benefits in all aspects of planning, scheduling and controlling and monitoring the time, cost specifications of projects. Kwak et el [23] research also presents how a systematic approach of project management maturity models for identifying and implementing project management practices and processes can increase the effectiveness and comprehensiveness of overall management practices.

Westhuijzen and Pelpola [24] conference paper on Project management of borehole programme stated that the Project Co-ordinator is responsible for co-ordinating and integrating activities across multiple, functional levels. Project management principles of plan, organise, lead and control, are therefore the ingredients that cement these operational islands into a continent of co-ordinated effort.

Black [25] revealed that major elements of project success include careful, thorough planning, followed by executing the plan with strong management control. The most important key to a project's success may be planning. Duffy and Thomas [26] also stated that poor planning leads to underestimation of resources which inevitably leads to inefficiencies and delays. Project closure is a significant and mandatory process, particularly in mega projects [27].

Project management tools and techniques play important role in the effective management of projects. Therefore, a good project management lies in the management tools and techniques used to manage the project. In groundwater construction, project management involves managing the resources - workers, materials, money, machines and schedules to complete a specified project on time and within approved costs

In order to bring the many components of a large project into control there is a large toolkit of techniques, methodologies, and tools. These techniques provide the tools for managing different components involved in a project: planning and scheduling, developing a product, managing financial and capital resources, and monitoring progress.

\section{Research Aim and Objectives}

This research studies the current practice of project management of groundwater construction projects in a developing country. The main objective was to review the practice of project management in groundwater construction projects in a developing country and the project life cycle: project initiation, planning, executing, monitoring/controlling, closing/evaluating processes commonly used in construction of groundwater projects in Ghana and recommend the best methodology and approach to project management practices 
in groundwater construction in a developing country

\section{Methodology}

This study was conducted in order to assess project management practice or processes in groundwater construction projects. The focus of the assessment was on the project management life cycle: project initiation, planning, executing, monitoring/controlling, closing/evaluating processes of the project. In order to analyse project management practices in the groundwater projects, a set of questions based on the project life cycle were employed in this study. The study focus on the three main groups who manage/implement groundwater construction projects in Ghana. The groups comprise owners (the government agency responsible for the projects, the private organisation and the individuals), consultants (consulting offices) and contractors working in the construction of groundwater projects. The profile of this groups are Project Managers, Assistant Project Managers, Project Coordinators, Project Directors, Consultants, Project Team Members, and Construction Manager in both public and private organisations with a huge responsible for the management of construction of the groundwater projects. The questionnaire was aimed to obtain data pertaining on the process and practice of project management life cycle in groundwater projects. The percentage distribution was used in the analysis of frequency distribution data. The questionnaire comprised two sections. The first section was designed to collect information about respondents, such as their position, experience, type of enterprise, etc. In the second section, respondents were invited to evaluate the project Management life cycle implementation in the construction of groundwater projects in Ghana.

\section{Data Analysis and Results}

The findings of the analysis of questionnaire survey are summarised as below:

\subsection{Questionnaire Responses}

120 copies of questionnaire were distributed to various individuals working in the groundwater construction in public and private organisations in Ghana and 84 were received (response rate of $70 \%$ ). Table 1 shows the percentage of questionnaire distribution and response.

Table 1. Questionnaire distribution and response.

\begin{tabular}{llll}
\hline Description & Number distributed & Number of response received & Percentage of number of responses \\
\hline Owners/Client's Representation & 50 & 38 & 76 \\
Contractors & 30 & 21 & 62.5 \\
Consultants & 40 & 25 & 70 \\
& 120 & 84 & 70 \\
\hline
\end{tabular}

The demographic characteristics of the respondents are given in Table 2.

Table 2. Demographic characteristics of respondents.

\begin{tabular}{lll}
\hline Demographic characteristic & Frequency & Percent \\
\hline Education & & \\
Project Management professional qualification & 25 & 30 \\
Post graduation & 10 & 12 \\
University & 29 & 35 \\
Pre-University & 20 & 23 \\
Type of Groundwater Organisations & & \\
Public (Government) Organisations & 67 & 80 \\
Private Organisations & 13 & 15 \\
Non-Profit Organisations & 4 & 5 \\
Role of respondents & & \\
Project Management role & 44 & 52 \\
Director/Senior Management & 4 & 5 \\
Contractor & 12 & 14 \\
Consultant & 18 & 22 \\
Construction Management & 6 & 7 \\
Number of years working experience & & \\
$0-5$ & 4 & 5 \\
$6-10$ & 7 & 8 \\
$11-15$ & 21 & 25 \\
$16-20$ & 37 & 44 \\
$21-25$ & 7 & 8 \\
$>25$ & 8 & 10 \\
\hline
\end{tabular}

The respondents were experienced groundwater construction Project Managers, Assistant Project Managers, Project Coordinators, Project Directors, Consultants, Project
Team Members, and Construction Manager (with average experience of 20 years in the construction industry).

As would be expected from their roles, these respondents 
also had significant years of experience in the construction industry. $68.33 \%$ of respondents had more than 15 years of experience. This showed that there was great depth in the experience possessed by the respondents.

\subsection{Research Findings}

The findings of the analysis of questionnaire survey are summarised as below:

\subsubsection{Project Management Processes}

Table 3 summarises the percentage of respondents who were involved in the project management life cycle processes. While an average of $74.2 \%$ of the respondents were involved in the project management life cycle processes an average of $25.8 \%$ were not involved in the project management life cycle processes.

Table 3. Summary of Percentage of respondents of the Project Management Processes.

\begin{tabular}{lll}
\hline \multirow{2}{*}{ PM Processes } & \% of Response & \% of Response \\
\cline { 2 - 3 } & Yes & No \\
\hline Executing Processes & 100 & 0 \\
Controlling Processes & 92 & 8 \\
Closing Processes & 75 & 25 \\
Planning Processes & 62 & 38 \\
Initiation Processes & 42 & 58 \\
& 74.2 & 25.8 \\
\hline
\end{tabular}

\subsubsection{Provision of Project Plan}

The survey indicates that public groundwater projects had provision of project plan for the management of the project whereas private projects has only $20 \%$ had provision of project plan as indicated in Table 4.

Table 4. Percentage Provision of Project Plan.

\begin{tabular}{lll}
\hline Provision of Project Plan & Yes $(\%)$ & No $(\%)$ \\
\hline Public Projects & 100 & 0 \\
Private Projects & 20 & 80 \\
\hline
\end{tabular}

i Project Planning Processes Considered During the Planning Phases

For the timing of consideration of project planning processes during the different planning phases for groundwater projects are summarised in Table 5. From Table $3,71.8 \%$ of the respondents did consider project planning processes during the different planning phases for groundwater projects.

Table 5. Showing Percentage of Project Planning Processes Considered During The Groundwater Construction Project.

\begin{tabular}{lll}
\hline Project Planning Processes Considered & Yes (\%) & No (\%) \\
\hline During design documentation phase & 83 & 17 \\
During project delivery phase & 79 & 21 \\
During commissioning phase & 67 & 33 \\
During concept development phase & 58 & 42 \\
& 71.8 & 28.2 \\
\hline
\end{tabular}

ii Coverage of Project Planning Processes

The coverage of planning processes during the project phases used presented in Table 6 and shows that $73 \%$ of the response cover planning processes during the project phases, while $27 \%$ did not.

Table 6. Coverage of Project Planning Processes Summary During the Groundwater Construction Project Phases.

\begin{tabular}{lll}
\hline Coverage of Project Planning processes & Yes (\%) & No (\%) \\
\hline During project delivery phase & 92 & 8 \\
During design documentation phase & 83 & 17 \\
During commissioning phase & 65 & 35 \\
During concept development phase & 52 & 48 \\
& 73 & 27 \\
\hline
\end{tabular}

iii Critical Factors Considered During the Planning Processes

The various response in regards to the consideration of important/critical factors during the planning processes are summarised in the Table 7.

Table 7. Summary of Critical Factors Considered in Planning Processes.

\begin{tabular}{lll}
\hline \multirow{2}{*}{ Rank } & Factors & Mean \\
\cline { 3 - 3 } & & Relative Weight \% \\
\hline 1 & Cost budgeting & 6.48 \\
2 & Cost estimating & 6.46 \\
3 & Activity sequencing & 6.38 \\
4 & Schedule development & 6.33 \\
5 & Activity duration estimating & 6.23 \\
6 & Project plan development & 6.02 \\
7 & Activity definition & 5.98 \\
8 & Scope planning & 5.81 \\
9 & Scope definition & 5.62 \\
10 & Resource planning & 5.62 \\
11 & Communications planning & 5.35 \\
12 & Procurement planning & 5.31 \\
13 & Quality planning & 4.79 \\
14 & Organisational planning & 4.74 \\
15 & Staff acquisition & 4.49 \\
16 & Risk identification & 4.01 \\
17 & Risk quantification & 3.57 \\
18 & Risk response development & 3.49 \\
19 & Solicitation planning & 3.30 \\
\hline
\end{tabular}

Table 7 shows that the most critical issues to be considered during the planning processes in the descending order of priority were:

(1) Cost Budgeting

(2) Cost Estimating

(3) Activity Sequencing

(4) Schedule Development

(5) Activity Duration Estimating

(6) Project Planning Development

(7) Activity Definition

(8) Scope Planning

(9) Scope Definition

(10)Resource Planning

The responses to the selection of contract strategy for the project delivery system were fixed price and negotiated contracting and these were the two common type of contract strategy in groundwater projects. Cost reimbursement and others like lump sum and admeasurement with price adjustment were not commonly used in groundwater projects. There were no responses where joint venture contract was 
used. The results of the questionnaire survey indicated that majority of groundwater projects used standard form of contract.

\subsubsection{Project Execution Processes}

The percentage of responses indicating the execution processes used to manage the groundwater project is summarised in the Table 8 .

Table 8. Showing Percentage of Project Execution Processes.

\begin{tabular}{lll}
\hline \multirow{2}{*}{ Execution Processes } & \% of Responses & \% of Responses \\
\cline { 2 - 3 } & Yes & No \\
\hline Project plan execution & 98 & 2 \\
Scope verification & 96 & 4 \\
Quality assurance & 90 & 10 \\
Information distribution & 85 & 15 \\
Contract administration & 82 & 18 \\
Team building & 80 & 20 \\
Source selection & 70 & 30 \\
Solicitation & 52 & 48 \\
\hline
\end{tabular}

From Table 8, it is found that the processes that is most frequently used for executing groundwater projects is (in the descending order of priority)

(1) Project plan execution

(2) Scope verification

(3) Quality assurance

(4) Information distribution

(5) Contract administration

(6) Team building

\subsubsection{Project Controlling Processes}

All the responses show that the groundwater projects had controlling processes. Various factors were used for controlling projects by different organisations. The responses were summarised in the Table 9.

Table 9. Summary of Project Controlling Processes.

\begin{tabular}{lll}
\hline \multirow{2}{*}{ Ranking } & Factors & Mean Relative \\
\cline { 3 - 3 } & & Weight $\%$ \\
\hline 1 & Overall change control & 17.65 \\
2 & Scope change control & 15.37 \\
3 & Cost control & 14.98 \\
4 & Scope control & 14.37 \\
5 & Quality control & 14.25 \\
6 & Performance reporting & 13.31 \\
7 & Risk response control & 10.08 \\
\hline
\end{tabular}

The questionnaire survey indicated that controlling processes that were considered to be highest priority and mostly adopted by the respondents for managing groundwater projects in the descending order of priority were:

(1) Overall Control

(2) Scope Change control

(3) Cost control

(4) Scope Control

\subsubsection{Performance Reporting and Monitoring Processes}

In the questionnaire survey, $76 \%$ of the respondents had performance reporting and monitoring processes during the groundwater construction project executing processes whereas $24 \%$ of the respondents did not have any reporting and monitoring processes in the groundwater construction project executing processes.

\subsubsection{Project Closing Processes}

The percentage of responses, which included the closing processes in the projects, is listed in the Table 10:

Table 10. Percentage of Project Closing Processes.

\begin{tabular}{lll}
\hline \multirow{2}{*}{ Closing processes } & \% of Response & \% of Response \\
\cline { 2 - 3 } & Yes & No \\
\hline Contract Close-out & 87 & 13 \\
Administration Closure & 46 & 54 \\
& 66.5 & 33.5 \\
\hline
\end{tabular}

From the table above, an average of $66.5 \%$ of responses indicated that the projects had closing processes (contract close-out and administration closure) whereas an average of $33.5 \%$ of responses do not have the closing processes with no administration closure as $54 \%$.

\subsubsection{Project Outcomes Review}

The questionnaire results showed that $70 \%$ of the respondents indicated that project outcomes are reviewed and the results recorded to determine the effectiveness of the project management processes. Whereas $30 \%$ of the respondents indicated that there were no project outcomes reviewed during groundwater construction project.

Involvement of Project Outcomes Review

The Table 11 below summarised the percentage of parties who involve in the project outcomes review.

Table 11. Percentage of Parties involvement in the Project Outcomes Review.

\begin{tabular}{ll}
\hline Parties & \% \\
\hline Project Manager & 75 \\
Client's Representative & 50 \\
Project Consultant & 45 \\
Stakeholders & 40 \\
Users & 25 \\
Construction Manager & 18 \\
Contract Manager & 15 \\
Quality Assurance Manager & 10 \\
General Manager & 8 \\
Procurement Manager & 3 \\
Suppliers & 3 \\
Subcontractors & 0 \\
Others & 0 \\
\hline
\end{tabular}

From Table 11, the respondents indicated the parties which are mostly involved in the project outcomes review in the descending order of priority include:

(1) Project Manager

(2) Client's Representative

(3) Project Consultant

(4) Stakeholders

Those who are least involved in the review are

(1) General Manager

(2) Procurement Manager

(3) Suppliers 


\section{(4) Subcontractors}

\subsubsection{Evaluation of Project Management Processes and Procedures}

The percentage of respondents, which indicated the evaluation of project management processes and procedures are summarised in the Table 12.

Table 12. Percentage of Evaluation of Project Management Processes and Procedures.

\begin{tabular}{lll}
\hline \multirow{2}{*}{ PM Processes and Procedures } & \%of Response & \% of Response \\
\cline { 2 - 3 } & Yes & No \\
\hline Executing Process es & 90 & 10 \\
Controlling Processes & 80 & 20 \\
Planning Processes & 71 & 29 \\
Closing Processes & 41 & 59 \\
Initiating Processes & 38 & 62 \\
& 64 & 36 \\
\hline
\end{tabular}

From Table 12, it is shown that an average of $64 \%$ of the response evaluated all the project management life cycle processes and procedures while an average of $36 \%$ did not. The table also show that the issues, which are mostly evaluated by the project management life cycle processes in the descending order of priority are:

(1) Executing Processes

(2) Controlling Processes

(3) Planning Processes

(4) Closing Processes

(5) Initiating Processes

a) Conformance to Project Time

The percentage of responses that indicated the extent of conformance to project time is listed in Table 11.

Table 13. Percentage of Conformance to Time.

\begin{tabular}{ll}
\hline Results conformance to Project Time & $\mathbf{\%}$ \\
\hline Exceeding 20\% project time & 51 \\
Exceeding 15-20\% project time & 25 \\
Exceeding 5-10\% project time & 12 \\
Exceeding 10-15\% project time & 8 \\
On time and exceeding 1-5\% project time & 4 \\
\hline
\end{tabular}

From Table 13, 10 of the respondents indicated the time of a project was exceeded by $100 \%$. From the table, only $4 \%$ of the respondents indicated that the projects were completed on time or with time not exceeding $5 \%$ whereas $51 \%$ of the projects exceeded over $20 \%$ of the project time.

b) Conformance to Project Cost

The percentage of responses that indicated the extent of conformance to project cost was listed below.

Table 14. Summary of Percentage of Conformance to Project Cost.

\begin{tabular}{ll}
\hline Results conformance to Project Cost & $\%$ \\
\hline Exceeding over $20 \%$ budget & 53 \\
Exceeding $15-20 \%$ budget & 19 \\
Exceeding $5-10 \%$ budget & 13 \\
Exceeding $10-15 \%$ budget & 10 \\
Within budget and exceeding budget $1-5 \%$ & 5 \\
\hline
\end{tabular}

From Table 14, 53\% of the project exceeded over $20 \%$ of the project budget. Only $5 \%$ of the respondents indicated that the projects were completed on budget or with budget not exceeding $5 \%$, whereas 4 of the response indicated the cost of the project exceeded by $500 \%$.

\subsubsection{Overall Project Performance}

The table below showed the percentage of respondents, which indicated the assessment on overall performance of the project.

Table 15. Percentage of Overall Project Performance.

\begin{tabular}{ll}
\hline Overall Project Performance & \% of Response \\
\hline Good & 50 \\
Very Poor & 25 \\
Excellent & 10 \\
Poor & 8 \\
Fair & 7 \\
\hline
\end{tabular}

From the above table $15,60 \%$ of the responses indicated that the overall performance of the project was assessed to be good to excellent whereas $40 \%$ of the responses showed that the overall performance had achieved fair to very poor.

\subsubsection{Recommendation of Improvement}

The questionnaire results indicated that $65 \%$ of the respondents conducted lesson-learned exercise, recommended improvements and documented for application in future projects while $35 \%$ of the respondents did not conducted lesson-learned exercise, recommended improvements and documented.

\section{Evaluation and Discussion of Results}

The project management practice in a developing country in groundwater construction projects in Ghana was evaluated with reference to the data obtained by questionnaire survey. The results of evaluation of this research are discussed in the following sections.

\subsection{Project Management Practice}

The questionnaire focuses on investigating the most implemented common project management life cycle processes and procedures (Initiating, Planning, Executing, Controlling and Closing/Evaluating). Table 1 shows the percentage of respondents who were involved in the project management processes. The results indicate that most of the respondents were involved in the executing and controlling processes while only few were involved in the planning (Yes $62 \%$ and No 38\%) and initiating (Yes 42\% and No 58\%) processes.

\subsection{Project Initiating Processes}

Most of the groundwater construction projects had initiating processes but only few of key players involved in the process. Less than half of the respondents are involved in the processes. Most of the groundwater projects in the developing country are foreign aid sponsor, and the project initiating processes are done by the top management, planners and political leaders. This indicated that the key 
project teams are not playing a dominant role in the initiating process.

\subsection{Project Planning Processes}

Although most of groundwater projects had the provision of project plans for the delivery of project, the project plans were not prepared and developed in accordance with the good practice of project management. Most of the project plans were considered and prepared in the project documentation phase rather than in the initiation and concept development phase when the opportunities add value is greater for the benefits of project.

The results indicated that most of the project planning processes was covered during the design documentation and project delivery phase with less emphasis on the concept development phase and project commissioning phase. This revealed that insufficient attention and resources were paid to front end and the termination end of project life cycle.

Most of groundwater projects had considered the core planning processes during the project planning phase such as scope planning, scope definition, activity definition, activity sequencing, activity duration estimating, schedule development, cost estimating and cost budgeting. However, the critical factors affecting groundwater project such as risk identification, risk quantification, risk response, quality planning and communication planning were considered low priority during planning processes. This implied that most of groundwater projects had not made full use of project planning processes during the planning phase.

The contract strategy for delivery of most of project was traditional lump sum contract. Most groundwater projects used standard form of drilling contacts.

\subsection{Project Executing Processes}

Most respondents were involved in the execution process in the management of the projects such as project plan execution, scope verification, quality assurance, and information distribution. The results indicated that some of the respondents do not have any of the execution process in the management of their project such as team building, solicitation, and source selection.

\subsection{Project Controlling Processes}

Most of the projects had project controlling processes and procedures. This indicated that most of the project performance was regularly measured to identify variance from the plan.

Although project-controlling system were in the projects, mainly overall change, scope change, schedule, and cost controls with less weighting were given to performance reporting, quality control and risk response control. This meant that they were not considered as critical factors for project controlling process.

There was performance-based reporting system provided in most of the groundwater project. The reports were mainly used to monitor the progress of the project in terms of time, cost and scope during the construction period of the project. There were low percentage of performance reporting in the controlling process meant that most of the projects had poor collecting and disseminating performance information which includes status reporting, progress measurement, and forecasting.

\subsection{Project Closing/Evaluating Processes}

Most of groundwater projects had contract close-out while more than half of the projects did not have administration closure. This indicated that most of the groundwater Project Managers did not verify and document projects results to formalise acceptance of the product of the project by the sponsor, client, or customer. This also revealed that most of the Project Mangers did not collect the project records, ensure that they reflect final specification, analysis of project success and effectiveness, and archiving such information for future use.

Most of the projects did not have project outcomes review conducted upon completion of project. This indicated that most of the projects did not have project management and recommended improvements for application in future projects. For those projects having conducted project outcomes review, Project Manager, Client's Representative, Project Consultant, and Stakeholders were involved in the project review. They were key parties directly involved in the project outcome review. The survey results indicated that the $90 \%$ of the project under study were community projects, however only $25 \%$ of end users involved in the project closing and evaluating processes. The other parties who were significant or had indirect interests in the project were not usually included in the project outcomes review. They were General Manager, Quality Assurance Manager, Procurement Manager, Subcontractors and suppliers.

The success or failure issues, which were mostly, project outcomes review, focused on the implementation phase of the projects such as execution and controlling procedure. Less consideration was given to review the critical issues in the front end of the project process such as initiating and closure processes.

When the performance of projects is assessed, it is found that half of groundwater projects are considered to perform up to good whereas about $10 \%$ had achieved and performed excellent standard. These excellent groundwater projects were found to have completed on time and within project budget. About $25 \%$ of groundwater projects had very poor performance, it was also found that these projects were delayed and budget overspent.

\section{Summary and Conclusions}

The main survey of contractors, owners and consultants as discussed in this research related to the construction of groundwater projects in Ghana. The main conclusions of the survey are as follows:

The survey showed that all of the entire three groups generally agreed that most of the problems in the 
groundwater construction projects are human and management problems. In practice, this phenomenon is expected to continue unless actions are taken to control these causes within the planned element of the design and construction works. Thus, good practice in planning, coordinating, control and monitor procedures needs to be recognised.

It is clear from the responses that the practice of project management in groundwater construction industry in Ghana is in mid-development. Most of the respondents are not involved in the planning and the initiating processes. The project plans were considered during design documentation and project delivery phases. The results indicated that most of the project planning processes was covered during the design documentation and project delivery phase with less emphasis on the concept development phase and project commissioning phase. This revealed that insufficient attention and resources were paid to front end and the termination end of project life cycle. The research result indicates that performance-base reporting during the controlling processes was lacking.

Most of the projects did not have project outcomes review conducted upon completion of project. The result revealed that most of the project did not collect the project records, ensure that they reflect final specification, analysis of project success and effectiveness, and archiving such information for future use. This indicated that most of the projects did not have project management and recommended improvements for application in future projects. For those projects having conducted project outcomes review, Project Manager, Client's Representative, Project Consultant, and Stakeholders were involved in the project review. They were key parties directly involved in the project outcome review.

\section{Recommendations}

Based on this study, and the developing countries in mind, some recommendations are given as follows:

(i) The scope of the project is defined and a project management plan is developed be taken in the early stages (conceptual and planning, and evaluating phases) of the groundwater construction projects. The project plans also includes establishing baselines or performance measures

(ii) Good management strategies would perhaps affect this situation positively more than any other remedies and can have short- and long-term effects.

(iii) The manpower, in both the technical and managerial levels in this industry should have their own knowledge updated by continuous professional development schemes. They needed to be familiar with project management techniques, procedures, and processes. This may be in form of conferences, seminars, and short and long-term training programmes in educational establishments.

(iv) Good project management in construction must vigorously pursue the efficient utilization of labour, material and equipment.

(v) A good project controlling and reporting systems should be in place. These systems provide for monitoring and feedback at all stages and enable comparison of schedules, budgets and team performance with project goals.

(vi) There should be a seriously monitoring, reviewing and auditing project activities as often as necessary in order to evaluate its performance and compared with the projected targets.

\section{References}

[1] Bagayal, O., and Song, J., 2016, Empirical Study of Factors Influencing Schedule Delays of Public Construction Projects in Burkina Faso, Journal of Management in Engineering, Vol. 32, Issue 5.

[2] Ghana Statistical Service, Data Production Unit, (2016), 2010 Ghana Population Projection by Sex, 2010-2016 http://www.statsghana.gov.gh/docfiles/2010phc/Projected $\% 20$ population $\% 20$ by $\% 20$ sex $\% 202010 \% 20-\% 202016$.pdf.

[3] GYAU-BOAKYE $P$ and DAPAAH-SIAKWAN S. 2000. Groundwater as Source of Rural Water Supply in Ghana, Journal of Applied Science and Technology, Vol. 5, Nos. 1 \& 2, pp 77-86, 2000.

[4] GSS, Ghana Living Standards Survey Round 6 (GLSS6), 2014. Main Report. Ghana Statistical Services, Accra.

[5] LAUBE, W., AWO, M. and SCHRAVEN, B., 2008. Erratic Rains and Erratic Markets: Environmental change, economic globalisation and the expansion of shallow groundwater irrigation in West Africa. ZEF Working Paper Series, ISSN 1864-6638. Department of Political and Cultural Change Center for Development Research, University of Bonn.

[6] MOFA, 2004. Projected livestock population for 1997-2007. Ministry of Food and Agriculture, Accra, Ghana.

[7] AGODZO, S. K., 2003. Shallow well irrigation for shallot farming in the Keta Lagoon Area of Ghana. Journal of the Ghana Institution of Engineers. Volume 1, Number 1:pp1-6.

[8] DARKO, P. K., DUA, A. A., and DAPAAH-SIAKWAN, S. 2003. Groundwater Assessment: An element of integrated Water Resources Management: the case of Densu River Basin. Technical Report for the Water Resources Commission, Accra, Ghana.

[9] Grönwall, J., 2016, Self-supply and accountability: to govern or not to govern groundwater for the (peri-) urban poor in Accra, Ghana, Environ Earth Science 75(6), p.1163.

[10] Chakava Y, Franceys R, Parker A., 2014, Private boreholes for Nairobi's urban poor: the stop-gap or the solution? Habitat International Vol. 43, pp. 108-116.

[11] Grönwall J T, Mulenga M, McGranahan G., 2010, Groundwater, self-supply and poor urban dwellers A review with case studies of Bangalore and Lusaka. IIED Human Settlements Working Paper Series, Water and Sanitation, 26, November 2010 http://pubs.iied.org/pdfs/10584IIED.pdf. 
[12] Okotto L, Okotto-Okotto J, Price H, Pedley S, Wright J., 2015, Socio-economic aspects of domestic groundwater consumption, vending and use in Kisumu, Kenya. Appl Geography Vol. 58 pp. 189-197.

[13] QUARTY, Jr., E. L., (1996). "Development Project through Build-Operate Schemes: their Role and Place in Developing Countries". International Journal of Project Management. 1996, Vol. 14, No. 1, pp. 47-52.

[14] PMI, “A Guide to the Project Body of Knowledge" (PMBOK) Project Management Institute (1996).

[15] ASTON, B. 2016, Project Management Life Cycle: The Complete Guide, $\mathrm{https}$ ://thedigitalprojectmanager.com/project-managementlife-cycle/.

[16] ProjectCubicle, 2018, Project Life Cycle Phases for Project Management https://www.projectcubicle.com/five-projectlife-cycle-phases/.

[17] ENDE, L. D. and MARREWIJK A. 2014, The ritualization of transitions in the project life cycle: A study of transition rituals in construction projects, International Journal of Project Management, Vol. 32, Issue 7, pp. 1134-114

[18] GOLINIA, R., KALCHSCHMIDTA, M. and LANDONIB, P. 2015, Adoption of project management practices: The impact on international development projects of non-governmental organizations, International Journal of Project Management, Vol. 33, Issue 3, pp. 650-663.

[19] MUSPRATT, M. (1987). "Conditions Affecting Project in Less Developed Countries". Project Management. Vol. 5, No. 1, pp. 45-53.
[20] CODAS, M. (1987). "Development of project Management in Brazil - a Historical Overview". Project Management. Vol. 5, No. 3, pp. 144-148.

[21] CASH, C. and ROBERTS, F. (1992). "Elements of successful project Management". Journal of Systems Management. 1992, pp. 10-12.

[22] ABBASI, G. Y. and AL-MHARMAH, H. A. (2000) "Project Management Practice by the Public Sector in Developing Country". International Journal of Project Management. Vol. 18, No. 2, pp. 105-109.

[23] KWAK, Y. H., SADATSAFAVI, H., WALEWSKI, J., and WILLIAMS, N. L., 2015, Evolution of project based organization: A case study, International Journal of Project Management, Vol. 33, Issue 8, pp. 1652-1664.

[24] VAN DER WESTHUIJZEN, D. and PELPOLA, K., 1994. Project management of borehole programme. IN: Pickford, J. et al. (eds). Affordable water supply and sanitation: Proceedings of the 20th WEDC International Conference, Colombo, Sri Lanka, 22-26 August 1994, pp.124-127.

[25] BLACK, K. (1996). "Causes of project Failure: A survey of Professional Engineers”. PM Network, November 1996, pp. 21-24.

[26] DUFFY, P. J. and THOMAS, R. D. (1989). "Project Performance Auditing". Project Management. Vol. 7, No. 2, May 1989, pp. 101-104.

[27] ZOHREHVANDI, S., KHALILZADEH, M., HAJIZADEHB, M., and CHERAGHI, E., 2017, Planning project closure phase in combined cycle power plant projects, Procedia Computer Science, Vol. 121, pp. 274-281. 